\title{
Erratum to: Earthworms, litter and soil carbon in a northern hardwood forest
}

\author{
Timothy J. Fahey · Joseph B. Yavitt • Ruth E. Sherman • \\ John C. Maerz • Peter M. Groffman • Melany C. Fisk • \\ Patrick J. Bohlen
}

Published online: 23 May 2013

(C) Springer Science+Business Media Dordrecht 2013

\section{Erratum to: Biogeochemistry \\ DOI 10.1007/s10533-012-9808-y}

We would like to point out the following correction to the original article. In Fig. 5, the X-axis label is in error: on the right-hand side it now reads "no worm" whereas it should read "worm".

The online version of the original article can be found under doi:10.1007/s10533-012-9808-y.

T. J. Fahey $(\bowtie) \cdot$ J. B. Yavitt · R. E. Sherman

Department of Natural Resources, Cornell University, 12 Fernow Hall, Ithaca, NY 14853-3001, USA

e-mail: tjf5@cornell.edu

J. C. Maerz

Warnell School of Forestry and Natural Resources, University of Georgia, 180 E Green Street, Athens,

GA 30602-2152, USA

P. M. Groffman

Cary Institute of Ecosystem Studies, Box AB,

2801 Sharon Turnpike, Millbrook, NY 12545, USA

M. C. Fisk

Department of Zoology, Miami University,

212 Pearson Hall, Oxford, OH 45056, USA

P. J. Bohlen

Department of Biology, University of Central Florida,

P.O. Box 162368, Orlando, FL 32816-2368, USA 